\title{
MIRE TANITTOTT MEG BENNÜNKET A COVID-19 JÁRVÁNY? - A NEVETNIKÉK ALAPÍTVÁNY TAPASZTALATAI
}

\section{KAPITÁNYNÉ LÉGRÁDI ÉVA - KŐMÚVES GLÓRIA²}

\section{DOI: https://doi.org/10.53585/OnkSzem.2021.2.70-77}

\section{Absztrakt}

Az esettanulmány célja az volt, hogy bemutassa a COVID-19 járvány Nevetnikék Alapítvány múködésére gyakorolt hatását. Ehhez először is ismertettük az alapítvány vírushelyzet előtti, alaptevékenységét. Bemutattuk az önkéntes-kiválasztási folyamatunkat is, mivel a kórházi látogatóprogramnak köszönhetően egy olyan, főleg rendszeres önkéntesekből álló bázisra tudtunk támaszkodni, ami nagyban hozzájárult ahhoz, hogy a vírushelyzet okozta változásokra gyorsan és hatékonyan tudtunk reagálni. Ezt követően arról számoltunk be, hogy mit kellett újragondolni, miután a szigorítások következtében a kórházi látogató programot és a mese falfestést sem tudtuk személyesen folytatni. Kitértünk azokra a kihívásokra, amelyekkel Pécsen szembesültünk a COVID-19 járvány következményeként. A kialakult helyzetre adott gyors reagálásnak köszönhetően önkénteseinkkel idősek számára bevásárló szolgálatot szerveztünk, hogy a legveszélyeztetettebbek korosztálynak is biztosítsunk érintésmentesen élelmiszer és gyógyszer bevásárlást. Ezen felül önkéntesek bevonásával szájmaszkvarró csoportot hoztunk létre és az elkészült darabokat kórházakba, gyermekotthonokba szállítottuk be, mert a tavaszi időszakban még hiánycikknek számítottak a maszkok. Az otthonról dolgozó szülők és otthon maradó óvodás és iskolás gyermekeknek pedig interaktív online foglalkozásokat dolgoztunk ki, hogy enyhítsük a szülők terheit és hasznos időtöltést biztosítsunk a gyermekeknek. Végül pedig beszámoltunk az önkénteseink szervezésével és megtartásával kapcsolatos tapasztalatainkról, hangsúlyozva munkájuk fontosságát és nélkülözhetetlenségét.

Kulcsszavak: COVID-19 kihívásai, újratervezés, önkéntesség, Nevetnikék Alapítvány

What the COVID-19 pandemic has taught us? - Experiences of the Nevetnikék Fundation

\section{ÉVA KAPITÁNY LÉGRÁDI - GLÓRIA KŐMŰVES}

\section{Abstract}

The aim of the case study was to show the impact of COVID-19 on the functioning of Nevetnikék Foundation. First of all, we described the normal scope of activities which was characteristic before the virus. We also described the recruitment process of the volunteers as owing to the hospital visiting program, we had a basis of regular volunteers we could rely on. This contributed to our fast and effective reacting to the changes caused by the virus. Then we reported about what we had to rethink after the lockdown since we could neither continue the personal hospital visiting program nor the fairy tale wall painting project. We also referred to the challenges we had to face in Pécs due to COVID-19. As a reaction

\footnotetext{
${ }^{1}$ Kapitányné Légrádi Éva mentor, marketinges, Nevetnikék Alapítvány

${ }^{2}$ Kömüves Glória elnök, Nevetnikék Alapítvány
} 
to the given situation, we organized a voluntary shopping service for people living with chronic illness and for the elderly to provide contactless food and medicine supply for the most endangered population. Above that, we created a face mask sewing group to share experience and work together. The masks were delivered to hospitals and orphanages since during the last spring period there was a shortage of these items in these institutions. We wanted to help parents who had to work from home, so we organized useful, interactive online sessions for their preschool- and school-age children. Finally, we reported about the experiences and difficulties we were facing in connection with the recruitment and the retention of our volunteers who make a valuable, multi-tasking job at the foundation.

Keywords: challenges of COVID-19 pandemic, redesign, volunteering, Nevetnikék Fundation,

\section{BEVEZETÉS - A NEVETNIKÉK ALAPÍTVÁNY BEMUTATÁSA}

A Nevetnikék Alapítvány egy 12 éve múködő pécsi szervezet, melynek fő célja a beteg gyermekek gyógyulásának elősegítése. A szervezet fő tevékenységei két csoportba sorolhatók:

- Játékos programok a fekvőbeteg kórházi osztályokon. A Pécsi Gyermekklinika minden osztályára szervezünk délutánonként játékos foglalkozásokat. Társasjátékozunk, bábozunk, mesét mondunk, kézműveskedünk, együtt zenélünk, vagy búvésztrükkökkel ejtjük ámulatba a gyerekeket, attól függően, nekik mihez van kedvük. Célcsoportunk a 0-18 éves korú gyermekek - csecsemők, kisgyermekek és serdülő gyerekek -, akiket valamilyen oknál fogva szüleik nem tudnak látogatni, és ezért kiemelt figyelmet kapnak tőlünk. Célkitúzésünk, hogy minden nap, minden osztályon, minden gyerekhez eljuthassunk.

- Mesefalfestés. A Pécsi Gyermekklinika, illetve más gyerekkórházak, gyerekvárók díszítését vállaljuk. A fehér, csempézett falakat színessé, gyerekbaráttá varázsoljuk, hogy a várakozás és bent tartózkodás terheit ezáltal is enyhítsük. A falfestések egy-egy cég támogatásával valósulnak meg, mely számukra felér egy csapatépítő tréninggel. Ehhez kapcsolódóan Pécsett először valósult meg interaktív mesefal projektünk a Pécsi Gyermekklinika ambulanciáján. Ez nem csak gyönyörü, színes festményeket, hanem a folyosóra szerelt, egyedi, készségfejlesztő játékokat is magába foglal.

A vírushelyzettel egyidőben kezdődött el egy újabb tevékenységi kör kialakítása. Játékkészítő workshopok keretében szeretnénk kézzel készített, ökotudatos, készségfejlesztő játékokat készíteni az ambulanciákon és kórházban megforduló gyermekek részére, amit ajándékba elvihetnek magukkal haza. A korlátozások következtében a workshopok még váratnak magukra, de már több játék prototípusa kész van és továbbiak pedig tervezés alatt állnak. 


\section{A COVID-19 JÁRVÁNY ELŐTTI ÖNKÉNTESEINK BEMUTATÁSA}

Kórházi programunk önkéntesei jellemzően 18 és 65 év közötti nők és férfiak. Egy részük egyetemista, főiskolás, akiket az elmúlt években leginkább a Pécsi Tudományegyetem Pszichológia alapszakról és az Egészségtudományi Karról sikerült személyes toborzás során bevonnunk. Önkénteseink több mint fele aktív korú, dolgozó felnőtt és alig három százalékuk nyugdíjas.

A kórházi programunkhoz történő csatlakozás első lépése egy jelentkezési lap kitöltése, amelyet egy személyes interjú követ és ezek alapján dől el, hogy a jelentkező tovább kerül-e a betanulás szakaszába. A felkészítés körülbelül két hónapig tart, és az önkéntesek egyrészt ez alatt az idő alatt végzik el az egészségügyi és pszichológiai képzést, ahol a különféle betegségtípusokkal együtt járó fizikai és pszichés tünetek sajátosságait tanulják meg. Másrészt azt az alapképzést, amelyen a kórházi látogatással és a használható eszközökkel kapcsolatos legfontosabb információkat, alkalmazható foglalkozás típusok sajátosságait és a betartandó szabályokat sajátítják el. Harmadrészt kommunikációs alaptréningen vesznek részt, ami a gyermekekkel történő későbbi kapcsolatfelvételt segíti elő célzott gyakorlatokkal. Ezzel párhuzamosan, az alapítvány régebbi önkénteseiből kiképzett mentorok vezetésével, három kórházi hospitáláson is részt vesznek. Ezt követi a bemutató foglalkozásuk, aminek keretében önállóan kell megtartaniuk a bent fekvő gyermekek számára egy kórházi foglalkozást. A sikeresen végzettek bekerülnek a kórházi program önkéntesei közé, majd pedig havi beosztások alapján, előre egyeztetett időpontokban végzik tevékenységüket. Mindezzel még nem ér véget a képzési szakasz, mert akik szeretnének egyik vagy másik (kézműves, bábos, mesemondó, zenés) foglalkozás típusra szakosodni, azoknak lehetőségük van úgynevezett mesterképzések elvégzésére is. Nagyon fontos szempont, hogy minőségi foglalkozásokat tartsunk az osztályokon, így félévente hirdetünk meg újabb és újabb belső képzéseket és ösztönözzük önkénteseinket arra, hogy legalább évente egy foglalkozáson vegyenek részt. A pszichiátria és az onkológia osztályokon csak olyan önkénteseket engedünk dolgozni, akik több mint egyéves, aktív önkéntes szolgálatot és célzott képzést teljesítettek, valamint meghallgatáson vettek részt.

A kórházi foglalkozásokat mindig ketten tartják, két óra időtartamban. Ahhoz, hogy minden gyermekhez eljuthassunk minden nap, folyamatosan fogadunk új önkénteseket. Egy jó évben 40 főt tudunk teljesen felkészíteni és általában a jelentkezők 40-50 százaléka válik 
programtartóvá. Mindig hangsúlyozzuk, hogy hosszú távra keresünk rendszeres önkénteseket, ami azt jelenti, hogy heti rendszerességgel, de minimum havi 2-3 alkalommal számítunk rájuk. Ugyanis, rengeteg időt, energiát és pénzt fektetünk a képzésükbe, fejlesztésükbe, szupervíziójukra és nem mellékesen a közösséghez tartozás élményét szeretnénk számukra megadni a folyamatos csapatépítő alkalmainkkal.

A mesefalfestő projektek esetében inkább alkalmi önkéntesekről beszélhetük, hiszen minden projekthez más-más cégek, szervezetek, baráti társaságok jelentkezését várjuk, akik egy rövid betanulást, képzést követően készen állnak arra, hogy festő koordinátorunk vezetésével és a megfelelő eszközök biztosításával, szebbé tegyék az egészségügyi intézményekben, a gyermekeket fogadó környezetet.

\section{HOGYAN ÉRINTETTE A COVID-19 JÁRVÁNY AZ ALAPÍTVÁNYT, ÉS MIT KELLETT ÚJRAGONDOLNI?}

A vírushelyzet azonnal és nagymértékben érintette, mondhatni fenekestől felforgatta az alapítvány múködését. Az év elején még nagy tervekkel és lendülettel vágtunk bele a munkába, egy-két hónap alatt elkészült a Szigetvári Kórház gyermekosztályán a pécsi Gyermekklinikáéhoz hasonló, interaktív mesefal, ami már csak a festésre várt. A szokásos pécsi és kaposvári kórházi látogatások mellett a felnőtt pszichiátriai programunkat is elkezdtük, ami a betegekkel való társasjátékozást és jógázást jelentett. Bár tizenkét év tapasztalatával tartottuk meg ott is a foglalkozásokat, de mégis újak és váratlanok voltak a betegektől való visszajelzések, hiszen egy felnőtt mégiscsak másképp fejezi ki a háláját, mint egy gyermek.

Tavaly, 2020-ban, két hónap alatt 40 fő jelentkezett a kórházi programunkra, akik még a járvány előtt részt vettek előzetes interjún, és kommunikációs képzésen, amit havonta tartunk kezdőknek és haladóknak is. Bár úgy éreztük előttünk nincsenek akadályok, de egyik napról a másikra a kórházak bezártak. Azok a tevékenységek, amelyek tizenkét éven át mindenkinek szívszerelem projektjei voltak, hirtelen társadalmilag a legveszélyesebbnek túntek, hiszen „tömegeket küldünk be kórházakba”.

Mindent újra kellett gondolnunk, de először is ott szerettünk volna segíteni, ahol leginkább úgy éreztük, hogy szükség van rá ebben a hirtelen kialakult, bizonytalan helyzetben. Így meglévő önkénteseinkkel próbáltuk tartani a kapcsolatot online és telefonon, illetve bevonni őket az idősek számára történő bevásárló, élelmiszerosztó, szájmaszk-varró és online 
gyermekfelügyelő projektünkbe, amelyekről később részletesebben is írunk. Nem volt kérdés számunkra, hogy - hátradőlünk-e és várjuk, amíg újra mehetünk a kórházba, vagy - valami mást, hasznosat kell csináljunk. Azonnal átcsoportosítottuk meglévő, aktív önkénteseinket azokra a területekre, ahol úgy gondoltuk, hogy a társadalom legnagyobb hasznára tudunk lenni, és erőnkön felül is igyekeztünk teljesíteni program-vállalásunkat a tavaszi időszakban.

Aztán nyáron az enyhítéseknek köszönhetően újra mehettünk látogatni a Gyermekklinika legtöbb osztályára, de csak a meglévő önkénteseinkkel dolgozhattunk, mert nem volt lehetőség újak toborzására. Ez módot adott arra, hogy régi önkénteseinkkel még jobban összecsiszolódtunk. Egész évben, a helyzet ellenére is, 215 foglalkozást tartottunk meg személyesen, és 673 gyerekhez jutottunk el. Kihasználva a korlátozások lazítását, nyáron gyorsan felszereltük Szigetvárra és Kaposvárra is a tervezett interaktív mesefalas játékainkat. Bár a festések minden esetben külső helyszínen történtek meg, mégis remek érzés volt tudni, hogy mire eljön a második hullám, addigra ott tudunk hagyni valami olyat a gyermekosztályokon, ami színt visz a gyerekek kórházi életébe.

$A z$ őszi hullámra valahogy már mindenki készült, másképp védtük az egészségünket is, másképp a munkahelyeket is, így november közepéig megmaradt önkénteseinkkel meg tudtuk csinálni a kórházi látogatásainkat. Utána hónapokig online kórházi foglalkozásokat tartottunk, és a bent fekvő gyermekekkel walkie talkien keresztüli beszélgetésekkel és teraszos zenés foglalkozásokkal próbáltunk kapcsolatot tartani. Bár nagyon várjuk újra a személyes találkozásokat, kétségtelen, hogy ennek az online módszernek az elsajátítása új kapukat nyitott ki előttünk, és a tapasztalatokat hosszú távon is fogjuk tudni hasznosítani. Közben folyamatosan fejlesztettük magunkat, tanultunk új meséket, új búvész trükköket, gyakoroltuk a különböző dalok akkordjait. Készítettünk dúdolós füzeteket, vettünk új hangszereket, varrtunk rengeteg csendes könyvet, és kihasználtuk az időt, hogy készüljünk a következő, új játékkészítős projektünkre.

\section{MIT JELENTETT MINDEZ PÉCSETT, MILYEN KIHÍVÁSOK VOLTAK?}

Miután nem folytathattuk a kórházi látogatásainkat, alkalmazkodtunk az új helyzethez. Kihívás volt, hogy mivel egyetemista önkénteseink nagy része nem pécsi, így az online oktatásra való átállással ők hazamentek, és ennek következtében már csak online és telefonon tudtunk velük kapcsolatot tartani. Ezért az újonnan szervezett tevékenységeink nagy részébe, nem is tudtuk 
őket bevonni. A COVID-19 járvány alatti öt programot valósítottunk meg önkénteseinkkel: a bevásárló szolgálatot idősek számára, a szájmaszk varrást, adománygyưjtést és ételosztást, valamint az interaktív online foglalkozásokat.

Bevásárló szolgálat. Pécsett, a kialakult helyzetre reagálva, elsőként szerveztük meg az idősek számára a bevásárló szolgálatot, hogy a legveszélyeztetettebbek korosztálynak is biztosítsunk érintésmentesen élelmiszer, illetve gyógyszerellátást. Körülbelül 25 segítővel 50 főnek vásároltunk be rendszeresen az első hullám idején. Ennek a projektnek a kapcsán hadd osszuk meg az egyik nagy sikerélményünket. A helyi rendőrfőkapitányt sikerült megkérnünk, tájékoztassa az embereit arról, hogyha az utcán idősekkel találkoznak, hívják fel figyelmüket az önkéntes és ingyenes bevásárló szolgálatra, a telefonos elérhetőségek megadásával. Továbbá, a rendőrök azt is elmondták az időseknek, hogy feleslegesen ne kockáztassák egészségüket a kijárással, mert az alapítvány segít nekik. Ez az együttmúködés azért volt nagyon értékes, mert online felhívásainkkal pont ezt a korosztályt tudtuk legkevésbé elérni.

Szájmaszk varrás. A bevásárló-akcióval párhuzamosan önkénteseinkkel belefogtunk a szájmaszk varrásba. Hét fővel, összesen 700 maszkot varrtunk és az elkészült darabokat helyi kórházaknak, gyermekotthonoknak szállítottuk le, mivel tavaly tavasszal a maszkok még hiánycikkek voltak.

Adománygyüjtés-ételosztás. Ezen kívül még adománygyưjtést szerveztünk a helyi, rászoruló családok számára, akik személyesen kerestek meg minket nehézségeikkel, nagy bevásárlásokat szerveztünk nekik és 15 főnek vittünk ki élelmiszert, hónapokon keresztül. Így váltunk élelmiszerosztóvá, mert az a döntés született, hogy a befolyt támogatások száz százalékát arra fordítjuk, hogy minél többen éljék túl a krízist.

Interaktív online foglalkozások. Ezen felül pedig játékos, éneklős, kézmúves, rajzolós, beszélgetős online foglalkozásokat tartottunk olyan családok gyermekeinek, ahol a továbbra is dolgozni kényszerülő szülők terheit próbáltuk enyhíteni azokban az idősávokban, amikor lefoglaltuk a gyerekeket.

\section{TAPASZTALATOK AZ ÖNKÉNTESEK SZERVEZÉSÉVEL ÉS MEGTARTÁSÁVAL} KAPCSOLATOSAN

Ebben az elmúlt egy évben, amikor alig lehetett kórházi látogatásokat és mesefalfestéseket szervezni, egyáltalán nem volt lehetőségünk új kórházi önkéntesek toborzására, betanítására. 
Azonban, alkalmi önkénteseket tudtunk szervezni az új átmeneti tevékenységeink kapcsán, mint a szájmaszk varrás, idősek számára történő bevásárlás és a jelenleg is tartó csendes könyvkészítésre. Összesen 50 fővel dolgoztunk ezeken a projekteken.

Meglévő kórházi önkénteseink megtartása is nagyon nagy kihívást jelentett, hiszen amiért csatlakoztak hozzánk - hogy személyesen jelen legyenek a gyermekek mellett -, azt csak a szigorításokig tudtuk számukra biztosítani. Ugyanakkor a pandémia lehetőséget adott arra, hogy online foglalkozások kapcsán is kipróbálhatták magukat. Voltak olyanok is, akiket újonnan komponált Nevetnikék dalunk videóklip forgatásába tudtuk beszervezni, home videók beküldésére buzdítva őket.

Ezen felül kezdeményeztünk még online csapatépítő mikulás bulit, különleges karácsonyi rejtvényekkel fúszerezve, illetve idén tavasszal az egészségügyi dolgozók számára írtunk személyes verset és készítettünk együtt, külön névre szóló képeslapokat. Továbbá, egy olyan játékra hívtuk őket, aminek az volt a lényege, hogy postai úton kellett a nekik kisorsolt embereknek küldeni a megadott feladatok alapján verset, origami alkotást, recepteket, zeneszámokat, apró finomságokat, egy rövid, kedves üzenet kíséretében. A cél az volt, hogy éreztessük egymással, hogy gondolunk a másikra, lélekben vele vagyunk, habár személyesen nem tudunk együtt dolgozni, mégse érezze magát senki egyedül, elszigetelve. Egyébként is folyamatosan törekedtünk arra, hogy érdeklődjünk a hogylétük felől. Biztosítottuk azt a lehetőséget is, hogy jelentkezhessenek online szupervízióra.

Nemrég szerveztük meg pár lelkes önkéntesünkkel a Jerusalema tánc kihívás forgatását is, amihez országszerte már nagyon sok más szervezet is csatlakozott. Az elkészült rövid videónk is arról árulkodik, hogy mennyi lelkesedés, szeretet árad a kis csapatunkból és mennyire összetartunk még a nehéz időkben is. Ennek ellenére, akármennyire is szerettük volna megtartani az önkénteseink teljes csapatát, sajnos egy nagymértékű, 27 százalékos lemorzsolódást. Arra kell felkészülnünk, hogy nagyon sok időt, energiát és anyagi ráfordítást fog jelenteni az új önkéntesek toborzása és betanítása, miután a vírushelyzet normalizálódik. Kis csapatunk tavasszal, amennyire tudta, több fronton is kivette részét a tűzoltásból. Az azonban nagyon nagy kihívást jelentett és jelent azóta is, hogy nem tudunk megjelenni olyan rendezvényeken, ahol lehetőségünk nyílna személyesen megismertetni az emberekkel az alapítvány tevékenységét és egyszeri vagy rendszeres adományozók felajánlásainak segítségével, biztosítani a program fenntartásához szükséges fedezetet. Ilyen volt például a 
családi Szamárfülfesztivál, ahol évekig jelen voltunk és csapatépítés szempontjából is nagyon meghatározó volt számunkra mindig az a pár nap.

Az elmúlt évben mindannyian egyszerre éltük át milyen a bezártság, a betegségtől való félelem, a tehetetlenség, a közösség hiánya, a kiszolgáltatottság. Mindazt a frusztráló érzést, amiból mi nap mint nap ki akarjuk zökkenteni a kórházban fekvő beteg gyermekeket, hogy mindezek mellett, vagy ellenére be tudjuk csempészni a napjaikba az örömöt, a játékot, a nevetést. Most, hogy egyszerre kerültünk ugyanabba a helyzetbe, már mindenki a saját bőrén tapasztalta meg, hogy ez nem is olyan egyszerű. Ezért tisztelet azoknak az önkénteseknek, akik ezzel szembeszállva, a csillagokat is lehozzák az égről a gyerekeknek. 